\title{
Periglacial sediment variations controlled by late Quaternary climate and lake level change at Elgygytgyn Crater, Arctic Siberia
}

\author{
GEORG SCHWAMBORN, GRIGORY FEDOROV, LUTZ SCHIRRMEISTER, HANNO MEYER AND HANS-W. HUBBERTEN
}

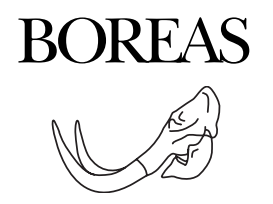

\begin{abstract}
Schwamborn, G., Fedorov, G., Schirrmeister, L., Meyer, H. \& Hubberten, H.-W.: Periglacial sediment variations controlled by late Quaternary climate and lake level change at Elgygytgyn Crater, Arctic Siberia. Boreas, 10.1111/ j.1502-3885.2007.00011.x. ISSN 0300-9483.

Late Quaternary sediments in a permafrost environment recovered from the Elgygytgyn Impact Crater were studied to determine regional palaeoenvironmental variability and infer past water-level changes of the crater lake. Stratigraphic analysis of a $5 \mathrm{~m}$ long permafrost core is based on various lithological (grain size, total organic carbon, magnetic susceptibility) and hydrochemical (oxygen isotope composition, major cation content) properties and pore ice content. The results show that alluvial sediments accumulated on top of cryogenically weathered volcanic rock. Changes in the hydrochemical properties reflect different stages of cryogenic weathering. The lithological characteristics mark the transition from an erosive site to a site with accumulation. This environmental change is linked to a relative lake level highstand at $>13000 \mathrm{yr} \mathrm{BP}$, when a shoreline bar was formed leading to slope sedimentation. Lake level dropped by $4 \mathrm{~m}$ during the Holocene.

Georg Schwamborn (e-mail: Georg.Schwamborn@awi.de),Lutz Schirrmeister, Hanno Meyer, Hans-W. Hubberten, Alfred Wegener Institute for Polar and Marine Research, D-14473 Potsdam; Germany; Grigory Fedorov, Arctic and Antarctic Research Institute, Bering Street, 199397 St. Petersburg, Russia; received 24th November 2006, accepted 10th August 2007.
\end{abstract}

The Elgygytgyn crater lake, NE Siberia (Fig. 1), yields the longest archive for Arctic terrestrial environmental and climate history (Nowaczyk et al. 2002; Melles et al. 2007). Studies of the periglacial rim of Elgygytgyn Crater are few (Schwamborn et al. 2006; Glushkova \& Smirnov 2007), but they have provided valuable insights into the catchment history. The crater is an impact dated to 3.6 myr before the present (Layer 2000) and the crater lake sediments are assumed to hold a palaeoenvironment and palaeoclimate archive reaching back to that time (Melles et al. 2005). The basin has a fill of at least $350 \mathrm{~m}$ of stratified sediments (Gebhardt et al. 2006), making it a deep drilling target in the near future. In previous geomorphologic and geological studies, it has been concluded that the area was not glaciated during the Quaternary (Glushkova 2001). Sediment accumulation in the lake may therefore have been continuous. Results from lake sediment studies of a $13 \mathrm{~m}$ long sediment core show that sediment variations reflect regional climate change during the last $250 \mathrm{kyr}$ (Nowaczyk et al. 2002; Asikainen et al. 2007; Lozkhin et al. 2007; Melles et al. 2007). Various glacial to interglacial changes are particularly well pronounced in the studied sediment properties. Furthermore, millennial-scale climate changes are recorded in the highresolution magnetic susceptibility data (Nowaczyk et al. 2002, 2007), i.e. data very similar to the $\delta^{18} \mathrm{O}$ record from Greenland Ice Cores (GISP/GRIP), including the occurrence of a Younger Dryas-like (YD) event. However, no comparisons have been made between the lake sediment record and contemporaneous terrestrial records (Schwamborn et al. 2006). The main objective of this article is to further our understanding of catch- ment response using the MIS 2-MIS 1 period as a test case. Here, we present a palaeoenvironmental and palaeoclimatic reconstruction based on studies of frozen sediments from the permafrost margin surrounding the lake. The terrestrial sediments were extracted north of the lake behind raised coastal bars that constrain the formation of ancient shorelines.

\section{Study area}

Elgygytgyn Impact Crater is a roughly circular depression, $18 \mathrm{~km}$ in diameter, and partially occupied by a lake $11 \mathrm{~km}$ in diameter (Fig. 1). The crater is superimposed on the Anadyr lowland and was formed in a volcanic plateau of the Upper Cretaceous (Belyi 1998). Volcanic strata consist of ignimbrites and tuffs mainly to the east, north and west, and andesitic rocks located in the south (Belyi 1998). The volcanic crater rim comprises peaks between 600 and $930 \mathrm{~m}$ a.s.l. (above sea level), and the lake level is $492 \mathrm{~m}$ a.s.l. Unconsolidated Quaternary deposits in a permafrost environment cover the crater plain surrounding the lake. The Quaternary deposits show a distinctly asymmetrical distribution with a broad fringe of loose sediment that is 500 to $600 \mathrm{~m}$ wide in the north and west and only 10 to $20 \mathrm{~m}$ elsewhere around the lake.

In 2003, the active layer was about $0.4 \mathrm{~m}$ deep in peaty silts and reached $0.5-0.8 \mathrm{~m}$ in sand, pebbles and gravels. The site is in the continuous permafrost zone with a MAGT (mean annual ground temperature) of about $-7^{\circ} \mathrm{C}$ at $5 \mathrm{~m}$ depth and MAAT (mean annual air temperature) of $-10^{\circ} \mathrm{C}$ at $3 \mathrm{~m}$ above the ground. Air 


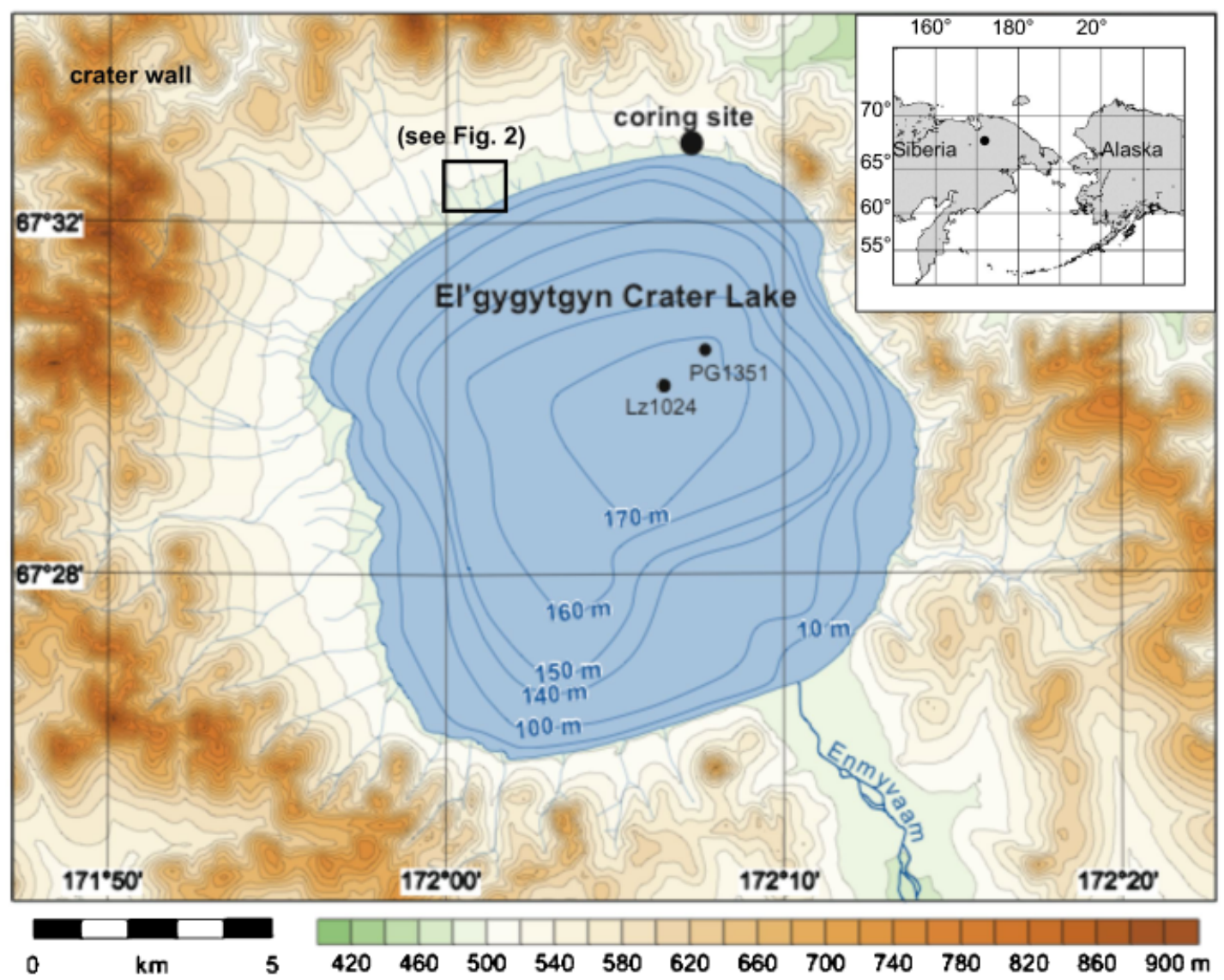

Fig. 1. Location of Elgygytgyn Crater and lake in Arctic Siberia (inset). The study site is located close to the northern shoreline. PG1351 and Lz1024 denote the sites where lake sediments have been extracted (Juschus et al. 2006; Melles et al. 2007).

temperature extremes in 2003 ranged from $-40^{\circ} \mathrm{C}$ to $+26^{\circ} \mathrm{C}$ and precipitation comprised $70 \mathrm{~mm}$ summer rainfall (June-September) and $110 \mathrm{~mm}$ water equivalent of snow (Nolan \& Brigham-Grette 2007). Humidity between September 2001 and August 2003 ranged around $80 \%$, with extremes from $17 \%$ to $100 \%$, the aridity peaks occurring in the summer months.

Currently, spring meltwater transports detritus from the catchment onto the lake ice and into the growing icefree margin. This sediment transport into the lake's shallow areas is probably responsible for further sediment release to the deep basin promoted by storm events occurring later during the open water season. Turbidites identified in the sediment column (Juschus et al. 2006) and in seismic profiles (Niessen et al. 2007) suggest that mass flows down the steep basin slopes are common.

The shoreline is composed of pebbles and gravels and generally measures 10 to $20 \mathrm{~m}$ across. The bowl-shaped and $180 \mathrm{~m}$ deep (at maximum) lake basin has nearshore shallows up to $1 \mathrm{~km}$ wide, which are delineated by a clear morphological drop at water depths of 10 to $12 \mathrm{~m}$ (Fig. 1). During the spring of 2003, major storms pushed lake ice onto the shore to form the uppermost shoreline in the lake. The storms annually modify the coastal pebble bar morphology 1 to $2 \mathrm{~m}$ in height up to a distance of 10 to $20 \mathrm{~m}$ from the lake. Since prevailing storms have either northerly or southerly directions (Nolan \& Brigham-Grette 2007), it is the northern and southern shorelines that are most affected by these ice-push processes. A lateral succession of up to four pebble bars is found 20 to $200 \mathrm{~m}$ around the lake. They are most conspicuous in the northern part of the basin (Fig. 2). The highest identified shorelines lie $4 \mathrm{~m}$ above the present lake level, which implies the maximum earlier lake level. The surfaces of the raised bars are no longer affected by ice push and lichens cover the exposed surface pebbles, indicating a considerable period since the surface was reworked (Glushkova \& Smirnov 2005).

Frozen slope sediments on the terrestrial side of the outer raised bar were cored and sampled to obtain the minimum age of the bar formation, i.e. assuming that the sloping sediments began accumulating after the bar had been deposited. The transition from the pebbly bar to the adjacent more finely grained slope sediments, which drape the foothill areas of the hinterland rocks, appears as a smooth surface, indicating that the older coastal bars were not pushed into the fine-grained deposits. Otherwise one might argue that the slope sediments are older than the coastal bar. Although this 


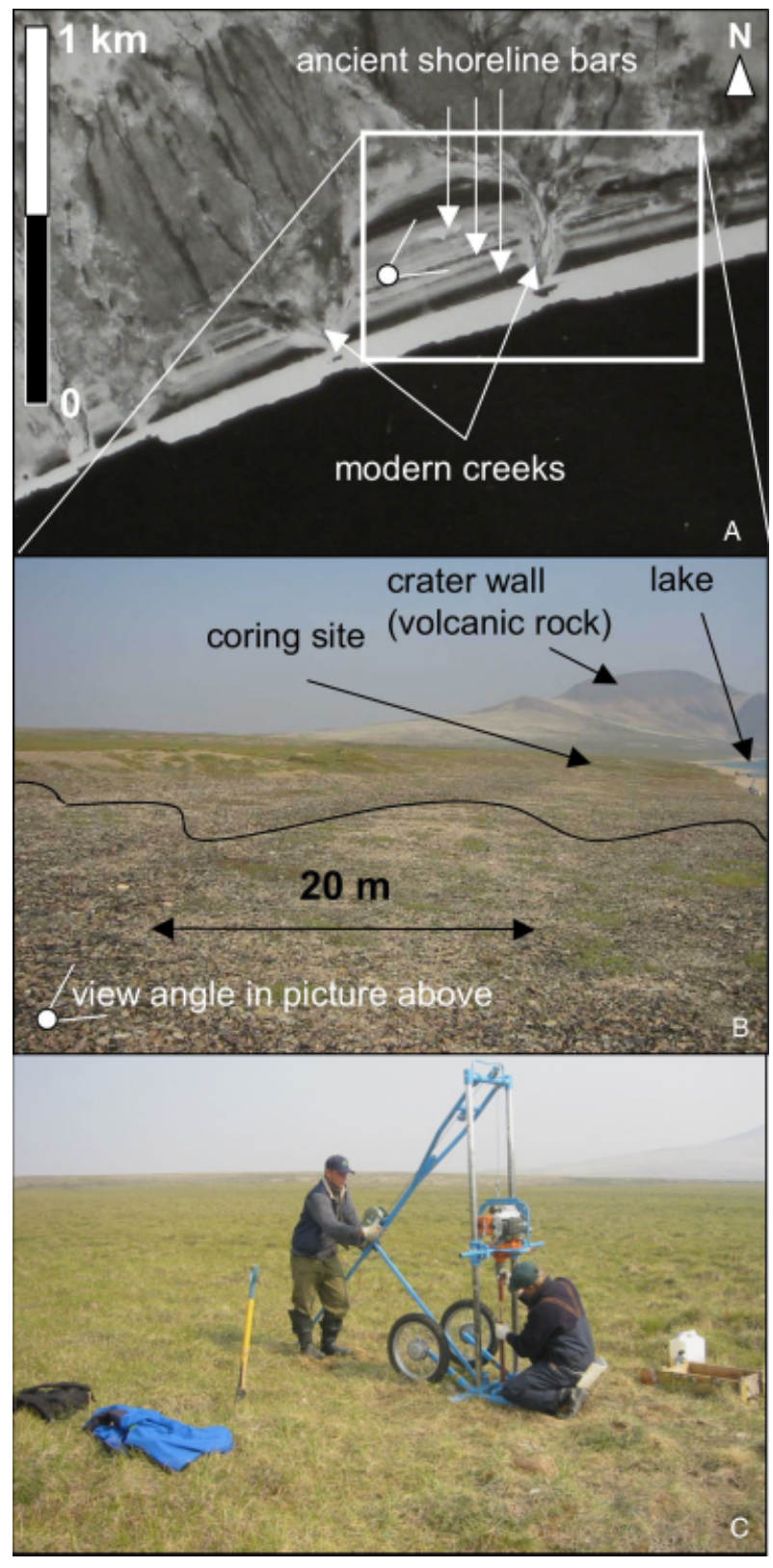

Fig. 2. A. Enlarged view of the coastal bar succession at the northern shoreline (image source: Corona satellite, USGS). B. The general setting shows a series of bars marking a shoreline retreat. The height of the bars (the black line) is 3-4 m above the lake level. C. Site of GPR profiles and permafrost coring behind the outer bar limits.

possibility cannot be excluded completely, some precautions were taken in order to minimize this uncertainty. The sampling site was: (1) selected in close proximity to the pebble bar, (2) pre-surveyed using GPR profiles to map horizontal sediment layering, (3) chosen to sample sediments without lake or shoreline sediments, and (4) the age determinations should reveal a systematic age-todepth relation excluding sediment reworking.

The permafrost was cored on a gently sloping $\left(<3^{\circ}\right)$ surface about $100 \mathrm{~m}$ from the northern shoreline (Fig. 2). The closest raised bar deposits were $20 \mathrm{~m}$ away.
Outcropping volcanic rocks lay about $1000 \mathrm{~m}$ north of the coring site. A boggy environment characterized the surface with a loamy substrate covered by grass. Surface drainage occurs mainly during spring snow-melt. The surface of the ground was dry in summer. Creeks are intermittent and ponds do not persist.

\section{Methods}

Prior to permafrost coring, $200-300 \mathrm{~m}$ long $50 \mathrm{MHz}$ ground penetrating radar (GPR) profiles were measured to observe the principal stratigraphic setting. A common value of electromagnetic pulse velocity in frozen ground $(0.13 \mathrm{~m} / \mathrm{ns})$ was used for the depth of signal penetration (Schwamborn et al. 2002). The profiles were used to determine a coring location with noncryoturbated and non-inclined layers $\left(67^{\circ} 32.837^{\prime} \mathrm{N}\right.$, $\left.172^{\circ} 07.528^{\prime} \mathrm{E}\right)$. Frozen sediments were recovered from this location to a depth of $5.1 \mathrm{~m}$ using a $6 \mathrm{~cm}$ diameter rotary permafrost corer powered by a $2.9 \mathrm{~kW}$ engine. Sediment was sampled at $10 \mathrm{~cm}$ or smaller intervals, depending on sediment characteristics. Field description of the sediments included grain-size distribution, colour, organic content and cryotexture. Frozen samples stored in polyethylene bags were weighed and given time to thaw. Supernatant water was extracted from the sediment samples and subsampled for stable isotope analysis $\left(\delta^{18} \mathrm{O}\right)$ and further hydrochemical analyses. The latter were obtained using a syringe with the water filtering through a $0.45 \mu \mathrm{m}$ acetate filter (Hasholt \& Hagedorn 2000). Electrical conductivity (EC) and pH using a WTW Cond340i conductivity meter and a WTW $197 \mathrm{~N}^{\circ}$ III $\mathrm{pH}$ probe were measured in the field. Further samples taken for analysis of the light soluble major cation content were acidified with concentrated $\mathrm{HNO}_{3}$ down to $\mathrm{pH}<2$. All samples were stored and tightly wrapped in HDPE bottles for transport to the laboratory.

The preserved soil moisture that forms ground ice reflects environmental and climatic changes. Major palaeoenvironmental and palaeoclimatic events have been resolved by interpreting the pore ice record (Burn et al. 1986; Murton \& French 1994; Kotler \& Burn 2000). Studying the water cycle, however, is a precondition for this interpretation, since its complexity demands careful consideration in palaeoenvironmental reconstructions when using stable oxygen isotopes. Several atmospheric and terrestrial sources of $\mathrm{H}_{2} \mathrm{O}$ (snow, rain, surface waters, ice wedges) were sampled throughout the field season (May-August 2003) to generate a minimum set of end members that contribute to pore ice. Water and ice were sampled at various sites in the southern crater margin. Application of stable isotope techniques within periglacial studies at Elgygytgyn Crater largely follows an approach outlined in a previous study (Schwamborn et al. 2006). 
After freeze-drying sediment samples in the laboratory, the gravimetric ice content was determined and expressed as total water content equivalent in weight percentage $(\mathrm{wt} \%)$. Representative samples along the sediment core were selected for detailed studies of grain-size distributions in the clay-silt-sand range determined by a laser particle analyser (LS200, Beckman Coulter, Inc.). The silt fraction is used as an indicator of the strength of cryogenic weathering. This is based on experimental studies, which demonstrate that cryogenic break-up of quartz grains results in silt-sized particles (Konishchev \& Rogov 1993). Repeated freeze-thaw cycles, such as occur in the active layer, accentuate this concentration of quartz in the silt fraction. Magnetic susceptibility was measured on single samples with a Bartington MS2E sensor and corrected for a uniform weight of $10 \mathrm{~g}$ per sample. Concentration is expressed in mass specific SI units $\left(\mathrm{m}^{3} / \mathrm{kg}\right)$. Relative mineral contents in the clay-sized fraction $(<2 \mu \mathrm{m})$ were determined with $\mathrm{X}$-ray diffraction on texturally orientated clay aggregates according to methods described in detail by Ehrmann et al. (1992) and Petschick et al. (1996). All samples were measured with a Philips PW 1820 goniometer using $\mathrm{CoK}_{\alpha}$ radiation $(40 \mathrm{kV}, 40 \mathrm{~mA})$. We focused on smectite (17 $)$, illite $(10 \AA ; 5 \AA)$, kaolinite (7.1 $\AA$; $3.58 \AA$ ) and chlorite (7.1 $\AA$; $3.54 \AA$ ).

Total organic carbon (TOC) was measured with a Vario EL III element analyser in samples $(5 \mathrm{mg})$ that had been treated with $\mathrm{HCl}(10 \%)$ at a temperature of $80^{\circ} \mathrm{C}$ to remove carbonate. International standard reference materials covering the measured range as well as double measurements were used to check for external precision. The following errors were accepted: $\pm 5 \%$ for TOC content $>1 \mathrm{wt} \%$; $\pm 10 \%$ for TOC content $<1 \mathrm{wt} \%$. Plant macro-remains (i.e. grass remains) were picked from individual core samples for AMS radiocarbon dating, which was done at the Leibniz Laboratory, University of Kiel. ${ }^{14} \mathrm{C}$ ages were calibrated into calendar years before the present (cal. yr BP) using the IntCal04 program (Reimer et al. 2004).

Pore ice stable isotope analysis used oxygen isotope compositions of $\mathrm{H}_{2} \mathrm{O}$ samples (e.g. Burn et al. 1986; Vasil'chuk \& Vasil'chuk 1998). Oxygen isotope ratios were measured on a Finnigan MAT Delta-S mass spectrometer and are presented using the $\delta$-notation representing the per mille relative difference of ${ }^{18} \mathrm{O} /{ }^{16} \mathrm{O}$ in a sample with respect to the Vienna Standard Mean Ocean Water (V-SMOW). The measuring procedure is described in Meyer et al. (2000). Internal $1 \sigma$ error is better than $0.1 \%$ for $\delta^{18} \mathrm{O}$. Cation concentrations aid palaeoenvironmental analysis (Kokelj \& Lewkowicz 1999) and were determined by summation of elemental occurrence ( $\mathrm{Ca}, \mathrm{Mg}, \mathrm{Na}$ and $\mathrm{K})$ using an ICP-OES Optima 3000 XL (PerkinElmer) instrument. Ion concentrations are expressed in milli-equivalents per litre $(\mathrm{meq} / \mathrm{L})$.

\section{Results}

\section{Large-scale stratigraphy and chronology}

GPR signal response from the permafrost has moderate quality due to high noise caused by antenna ringing, especially in the pebble bar deposits. Nonetheless, a GPR section running perpendicular to the pebble bar and continuing into the tundra soil displays a prominent undulating boundary between an upper unit and an underlying second unit at about $6 \mathrm{~m}$ sediment depth (Fig. 3). The faded boundary between the units is characterized by the presence of electromagnetic wave signal scattering (loss of coherent, laterally continuous reflectors). Coring results as presented below identify an upper unit of sedimentary deposits with a growing portion of volcanic debris with depth. The deepest part of the core reaches into the faded boundary shown in the GPR profile. The underlying unit is thus interpreted to represent volcanic bedrock. The boundary is interpreted to result from an irregular surface of a frostjacked volcanic basement. These interpretations are based on core evidence only, as no further comparisons with GPR signals in frozen volcanic rocks are available. It is remarkable that GPR profiles acquired in the western part of the crater show an electromagnetic boundary at a similar depth (Schwamborn et al. 2005). Here, solifluction sheets cover the undefined lower unit.

The substrate of the cored $5.1 \mathrm{~m}$ of sediments is composed of debris dominated by sand- and silt-sized

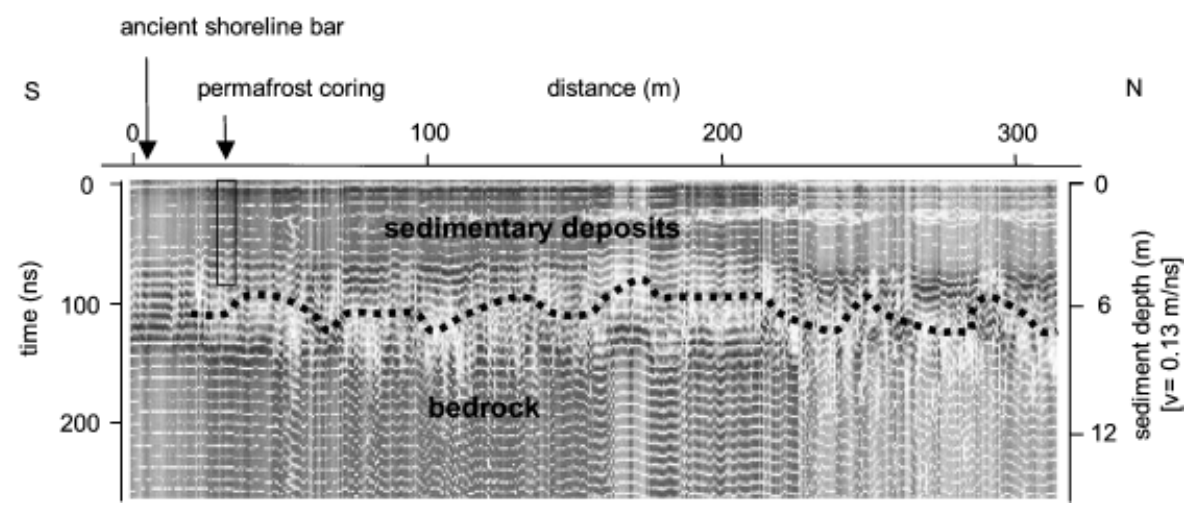

Fig. 3. Example of a $50 \mathrm{MHz}$ GPR profile recorded in the permafrost behind the shoreline bars. The profile displays an upper unit of loose frozen deposits, which was cored for sediment studies (rectangle). 


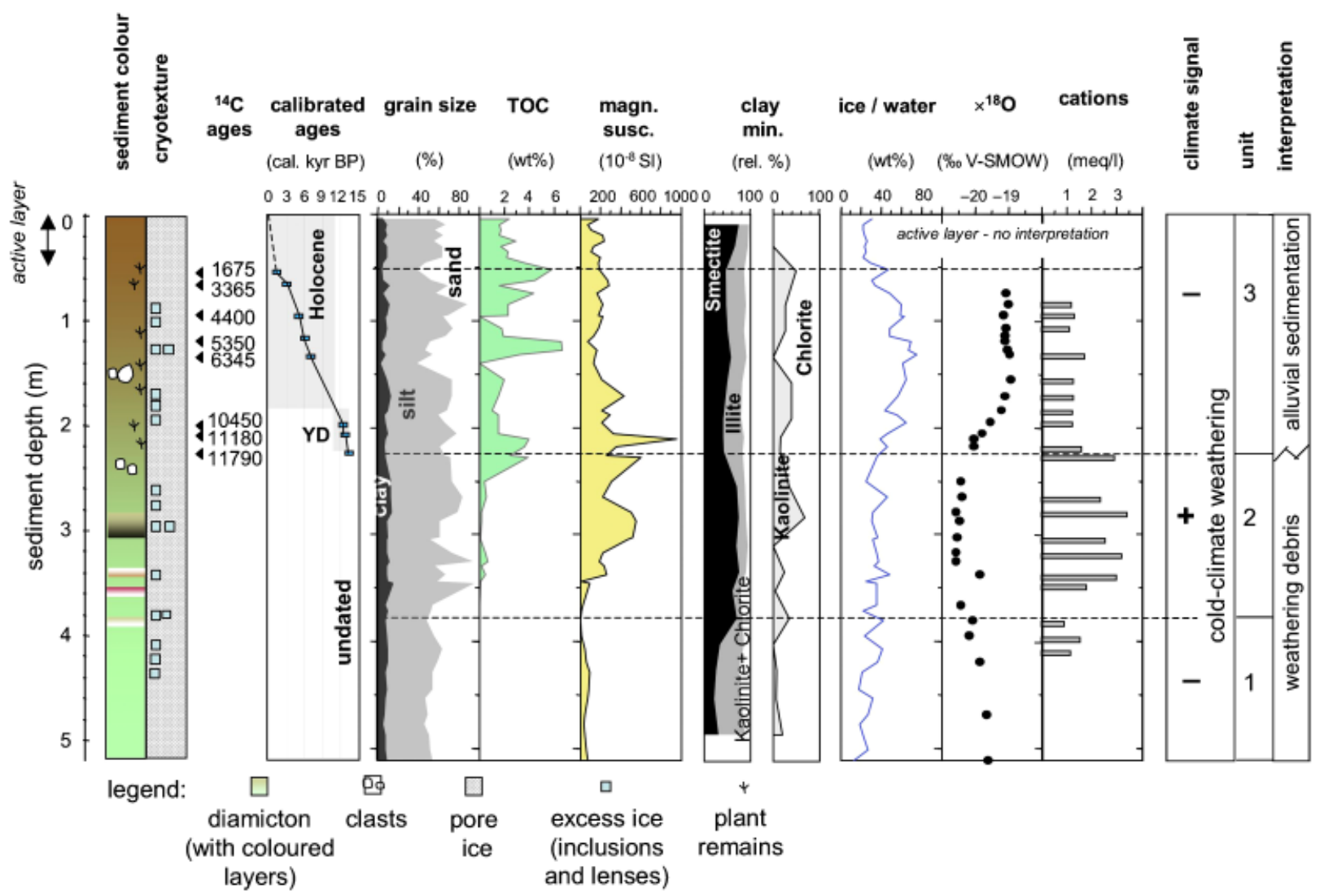

Fig. 4. Stratigraphic properties of frozen deposits with sediment units $1-3$ and an interpretative scheme.

grains with occasional pebble-sized, subangular clasts derived from volcanic rock (Fig. 4). The core material has clear colour differences with light green layers between 5.1 and $3.5 \mathrm{~m}$ core depth and red to brownish layers between 2.0 and $0.0 \mathrm{~m}$ core depth. The material between these sections is characterized by an alternation of decimeter layers of red and green substrate. The depth boundaries of these three macro-units were slightly revised after various sediment analyses were completed (see below). The fresh-appearing greenish and reddish colours resemble bedrock colours of volcanic bodies seen in the nearby crater walls. Whereas sediments below $2.3 \mathrm{~m}$ core depth are free of plant macro-remains, there are remains scattered throughout the upper part of the core. AMS ${ }^{14} \mathrm{C}$ dating of grass remains reveals a systematic age-to-depth correlation with maximum ages reaching down to 13000 cal. yr BP for sediments at $2.3 \mathrm{~m}$ core depth (Table 1). The core thus expands in time beyond the YD. The age of the deeper deposits is not known.

\section{Ice content}

Generally, the ground ice appears as pore ice. The ice content can vary in or between layers. High ice contents made of ice lenses or discrete $\mathrm{cm}$ layers of ice occur especially between $4.3-2.5 \mathrm{~m}$ and $2.0-0.8 \mathrm{~m}$ depth. The curve for the ice content (Fig. 4) illustrates that sediments deeper in the profile $(5.1-2.2 \mathrm{~m})$ contain less ice, ranging mostly between 20 and $40 \mathrm{wt} \%$ than sediments in the upper part of the profile $(2.2-0.0 \mathrm{~m})$ with generally higher values (up to $80 \mathrm{wt} \%$ ). The latter is a typical value for the ice-rich upper permafrost, which is common in Arctic Siberia and mostly associated with peat beds (Kienel et al. 1999), alluvial and slope deposits (Gravis 1969), or the polygenetic ice complex deposits of northern Yakutia (Kunitsky 1989; Tomirdiaro 1996; Schirrmeister et al. 2002). Recent active layer samples are characterized by low values of soil moisture $(\sim 20 \%)$.

\section{Sediment characteristics}

Sediment changes as resolved by measuring various sediment properties are used in the genetic interpretation and result in three sediment units (Fig. 4).

Sediment unit 1 (5.1-3.8 $\mathrm{m}$ depth) - The grain-size compositions are fairly constant in this unit, with relative amounts of clay around $10 \%$ and silt and sand with each between 40 and $50 \%$. Magnetic susceptibility is low $\left(<150 \times 10^{-8} \mathrm{SI}\right)$ and clay mineralogy has for the most part an equal distribution among the dominant 
Table 1. ${ }^{14} \mathrm{C}$ AMS ages of grass remains in the sediments. The $2 \sigma$ range is calculated with the INTCAL04 program (Reimer et al. 2004) to yield calibrated age intervals.

\begin{tabular}{|c|c|c|c|c|}
\hline Lab. no. & Dated material & Core depth (m) & AMS age $\left({ }^{14} \mathrm{C}\right.$ yr BP $)$ & $\begin{array}{c}\text { Calibrated age } \\
\text { interval (cal. yr BP) }\end{array}$ \\
\hline KIA24866 & Grass remains & 0.46 & $1675 \pm 25$ & $1526-1626$ \\
\hline KIA27258 & Grass remains & 0.52 & $3365 \pm 35$ & $3554-3693$ \\
\hline KIA27259 & Grass remains & 0.95 & $4400 \pm 110$ & $4813-321$ \\
\hline KIA27260 & Grass remains & 1.19 & $5350 \pm 45$ & $5999-6219$ \\
\hline KIA24867 & Grass remains & 1.32 & $6345 \pm 35$ & $7172-7331$ \\
\hline KIA24868 & Grass remains & 2.05 & $10450 \pm 60$ & $12124-12654$ \\
\hline KIA28243 & Grass remains & 2.10 & $11180 \pm 147$ & $12867-13303$ \\
\hline KIA28244 & Grass remains & 2.26 & $11790 \pm 242$ & $13152-14178$ \\
\hline
\end{tabular}

illite $(50 \%)$, smectite $(30 \%)$ and kaolinite and chlorite $(20 \%)$. There are slightly increasing portions of smectite and kaolinite towards the upper part of the unit. $\delta^{18} \mathrm{O}$ values of the ice range between -19.6 and $-20.1 \%$ (mean $\delta^{18} \mathrm{O}-19.9 \%$ ). However, there is a tendency towards lighter composition from the bottom to the top. The available cation measurements characterize this core part as one of low concentration $(<1.5 \mathrm{meq} / \mathrm{L})$.

This sediment unit is interpreted as a fairly uniform lithological environment deposited by autochthonous volcanic debris that has moderate signals of cryogenic weathering, i.e. a high silt portion and a moderate cation concentration in the intrasedimental ice.

Sediment unit 2 (3.8-2.2 $m$ depth) - The silt size dominates the middle core part, i.e. ranging between 40 and $80 \%$, with two distinct silt peaks at $3.4 \mathrm{~m}$ and $3.2 \mathrm{~m}$ depths. TOC appears from above $3.4 \mathrm{~m}$, however, with no macroscopic organic matter. Magnetic susceptibility values are comparably high and the highest value of $958 \times 10^{-8}$ SI marks the upper boundary of this unit. Smectite is the dominant clay mineral in this core part, with values as high as $78 \%$. Illite, in contrast, diminishes to values between 10 and $20 \%$. Kaolinite and chlorite show a growing portion of kaolinite. Sediment unit 2 is markedly characterized by the lightest oxygen isotope compositions (mean $\delta^{18} \mathrm{O}-20.4 \%$ ) and highest cation concentrations (up to $3.4 \mathrm{meq} / \mathrm{L}$ ).

This sediment unit is interpreted as a sequence of volcanic debris horizons admixed with portions of kaolinite. Very high silt portions and high cation concentrations indicate severe cold-climate weathering. The appearance of organic matter in the uppermost layers indicates the onset of pedogenesis.

Sediment unit 3 (2.2-0.0 $\mathrm{m}$ depth) - This sediment unit has two sand peaks with a sand content of up to $>50 \%$ and paralleled by high TOC contents ( $>6 \mathrm{wt} \%$ ). Intermediate magnetic susceptibility values characterize this part of the core with a mean of $200 \times 10^{-8}$ SI. The clay mineralogy illustrates a fairly homogeneous composition with illite increasing to a mean portion of $35 \%$ at the expense of smectite, when compared with unit 2.
Kaolinite is present in most parts of this unit, except for a layer at $1.3 \mathrm{~m}$ and within the active layer. A clear tendency towards a heavier oxygen isotope composition of the intrasedimental ice (mean $\delta^{18} \mathrm{O}-19.3 \%$ ) is described by the $\delta^{18} \mathrm{O}$ curve. This inflection, along with the occurrence of first macroscopic plant remains, is used to place the boundary between units 2 and 3, even though lithologically the transition appears smooth between the two.

Unit 3 is interpreted as an accumulation of alluvial sediments that have covered the volcanic debris underneath. Stable isotope compositions heavier than those of unit 2 in combination with the established chronology reflect that this environmental change is connected in time with the YD period at 13000 cal. yr BP. A decrease in cation contents to values lower than $1.7 \mathrm{meq} / \mathrm{L}$ characterizes this unit as one that is subject to moderate cryogenic weathering. Decreasing silt portions compared to those of unit 2 also support this interpretation. Increasing sand portions, on the other hand, could point to increasing import of alluvial material.

\section{Oxygen isotopes of ground ice}

The $\delta^{18} \mathrm{O}$ ratios along the profile range from $-19 \%$ to $-20.6 \%$ (mean $\delta^{18} \mathrm{O}-19.7 \%$ ), but no sudden deviations are observed in the $\delta^{18} \mathrm{O}$ curve along the permafrost profile (Fig. 4). With the exception of one sample at $3.3 \mathrm{~m}$, a similar process, most likely syngenetic ice formation, is assumed to have led to the formation of all types of ground ice (i.e. pore ice, ice lenses, ice inclusions, ice layers). The oxygen isotope values show distinct variations, supporting distinction of the sediment units; the transition from unit 1 up to unit 2 develops from heavier to lighter values, while the transition from unit 2 to unit 3 corresponds to a shift from relatively light to heavier values. This suggests an environmental change that continuously affected the ground and its ground ice formation. Although unit 1 and most parts of unit 2 are not dated, a Late Pleistocene age of the ground ice formation is assumed, as it represents the preceding environment of the dated 
sediments. The increase in $\delta^{18} \mathrm{O}$ after $13000 \mathrm{cal}$. yr BP may thus reflect climate warming following the YD.

\section{Oxygen isotopes in various sources}

The application of oxygen isotope signatures of snow, ice and water at Elgygytgyn Crater in this article is similar to that outlined in a previous study (Schwamborn et al. 2006), since the environmental conditions are much the same. A summary is given here to set up the interpretation context of the ground ice examined in this study.

The $\delta^{18} \mathrm{O}$ ratios of precipitation samples (rain) collected between May and August in 2003 in the Elgygytgyn Crater range widely from $-6.2 \%$ to $-25.9 \%$ o and have a mean value of $-14.6 \%$. Snow samples from May and August 2003 overlap with the rain values, but are generally lighter, with values between $-12.7 \%$ and $-29.0 \%$ (mean $\delta^{18} \mathrm{O}-19.9 \%$ ) (Fig. 5). Lake water and creek water, isotopically relatively light, range between $-18.9 \%$ and $-23.5 \%$ and are assumed to be fed by different proportions of snow-melt and rain, with a relatively high proportion of snow-melt. Sampling was carried out in June/July 2003 when snow patches were still present in the area. Secondary fractionation processes (such as evaporation) cannot be ruled out, but are certainly stronger for open water bodies than running water. Outcropping ice wedges at the southern margins of Elgygytgyn Crater have different oxygen isotope compositions depending on their age: $\delta^{18} \mathrm{O}$ ratios of ice veins reaching up into the active layer from the top of ice wedges have a mean value of $-20.4 \%$; small late Holocene ice wedges $(1.2 \mathrm{~m}$ in length and $1.0 \mathrm{~m}$ wide) a mean value of $-22.4 \%$; and large early Holocene ice wedges ( $2.5 \mathrm{~m}$ in length and $1.0 \mathrm{~m}$ wide) a mean value of $-23.5 \%$. The successively heavier values towards the present in the ice-wedge record indicate a trend towards warmer winters in the Holocene based on the preserved palaeo-winter precipitation. The inferred thermal change is also reflected in the growth of two differently sized ice-wedge generations during the Holocene, where the late Holocene ice-wedge polygons are only half the size of those of the early Holocene. $\delta^{18} \mathrm{O}$ values of cored ground ice (this study) are similar to the mean of snow precipitation, but it also overlaps with the rain composition, thus a mixture of these two sources is considered for the ground ice composition in the permafrost core.

\section{Discussion}

\section{Pre-Late Pleistocene (undated)}

Sediments of unit 1 are composed of poorly reworked volcanic material with very low ice content and the absence of any organic material. Taking into account that the topographic position of these sediments is approximately the same as the modern lake level, it is assumed that the lake level during the formation of unit 1 was well below the modern level. No sediments occur in unit 1 that could be linked with a lake environment. Usually, 'very coarse-grained' deposits like 'sandy gravels' occur in the shallower parts, i.e. the nearshore areas of the lake (Brigham-Grette et al. 2005: pp. 68, 109). The lake level should therefore be placed lower during the formation time of unit 1. Unit 1 is interpreted to represent in situ weathered volcanic bedrock. Oxygen isotope signatures lighter than typical Holocene values point to a Pleistocene age (undated) of cryogenic weathering processes that left the ground ice portion behind.

\section{Late Pleistocene - 13000 cal.yr BP}

Considerable amounts of kaolinite characterize much of units 2 and 3 . This may be directly linked to the volcanic weathering; however, it may also suggest that relics of an ancient weathering crust from upland sources have been admixed with the volcanic strata. Around Elgygytgyn Crater, kaolinite-bearing weathering crusts are preserved at altitudes $600-900 \mathrm{~m}$ a.s.1., which contain pollen spectra typical of the Pliocene (Glushkova et al. 1999; Glushkova \& Smirnov 2007). Weathering which produced kaolinite presumably occurred during a Pliocene warm period before Pleistocene climate cooling overprinted these formations.

The high amount of silt in the complete profile is an argument for a strong impact of cryogenic weathering
Fig. 5. $\delta^{18} \mathrm{O}$ values with standard deviations of various $\mathrm{H}_{2} \mathrm{O}$ sources from the study area. With the exception of 'intrasedimental ice (this study)', all other oxygen isotope signatures are taken from Schwamborn et al. (2006) for comparison.

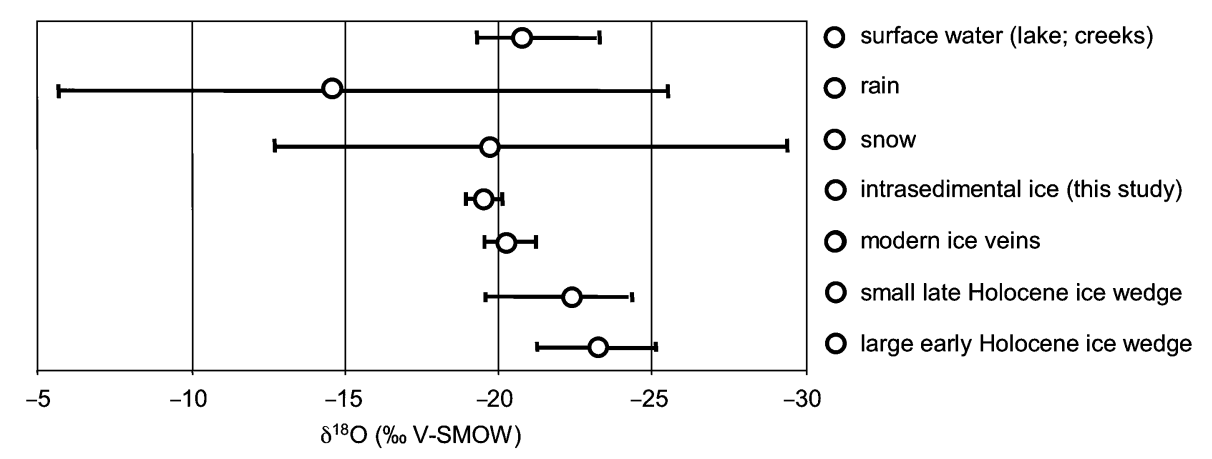


on sediment particles, especially in unit 2 . In particular, quartz grains that are subject to freeze-thaw dynamics disintegrate in situ and increase the amount of silt (Konishchev \& Rogov 1993). South-facing slopes in the study site have greater active layer depths than northfacing sites, where the exposure to solar radiation is reduced. Greater active layer depths on slopes in turn promote higher solifluction rates. Accumulation of silty deposits at southerly exposed sites has thus been found to be a characteristic feature of Siberian permafrost areas (Gravis 1969). Permafrost break-up of grains due to iterated thaw and freeze alternation in the active layer is considered a driving force in producing silt in the Elgygytgyn Crater. Ultimately, these silty substrates accumulate as lake sediments in the basin (Asikainen et al. 2007).

Sediment unit 2 is characterized by recognizably higher cation contents than the underlying and overlying units 1 and 3 . In periglacial cryogenic weathering of grains, the mineral surface increases and subsequently is subject to chemical weathering (Konishchev \& Rogov 1993). A stable surface during pre-YD time might have supported an increasing conductivity of aqueous solutions most likely due to cryogenic activity or to chemical weathering. The minima in the $\delta^{18} \mathrm{O}$ curve within unit 2 points to a change in palaeoclimatic conditions that affected the hydrological cycle. The ground ice mixture is assumed to be a two-component mixture between snow and rain. Figure 5 demonstrates that $\delta^{18} \mathrm{O}$ values of rain are generally heavier than those of snow, although they vary greatly and have a considerable overlap. A generally decreasing summer rainfall portion could have been the reason the ${ }^{18} \mathrm{O}$ values dropped during the time of unit 2 formation. Transport of ice meltwater upward from a deeper soil layer could have contributed to produce soil moisture with a comparably light isotopic composition (Sugimoto et al. 2003) as preserved in the ground ice of unit 2. Alternatively, snowfall may have had a considerably lighter isotope composition during that time and would thus point to lower atmospheric temperatures. The hydrochemical signatures in the ground ice indicate that no significant postdepositional moisture transport took place after its formation, documenting that the permafrost profile provided good preservation of nearly original hydrochemical signals.

\section{0 cal. yr BP-recent}

The upper unit 3 is characterized by the continuous occurrence of organic matter also containing macroremains (i.e. grass remains). Although the organic content fluctuates, AMS ${ }^{14} \mathrm{C}$ dating of grass remains in the sediments reveals a systematic age-to-depth correlation. Intense reworking, for example through cryoturbation or external forcing (e.g. shoreline transgression into the slope sediments), is not indicated. The dominance of sand-sized particles is associated with alluvial transport from uphill areas. Randomly occurring pebble-sized clasts may be relics from weathered bedrock. The Holocene evolution of unit 3 is interpreted to resemble modern conditions where a boggy environment receives import of particles by niveofluvial to alluvial slope wash mainly taking place during snow-melt and rainstorms. Pure fluvial sedimentation within creeks or riverbed is excluded, since the fluvial bedload as encountered in the crater lacks organic matter. The stability of the boggy environment during the Holocene was probably caused by its leeward position behind the shoreline bars. The uppermost $2.2 \mathrm{~m}$ of the cored sediments accumulated presumably at a sheltered site, where the sheltering effect prevented further transport into the lake basin. Principally, slope mobility and sedimentation may also be attributed to a geomorphological adjustment during a time of climatic transition (Vandenberghe 1995). Apart from local thresholds, the Pleistocene/Holocene cold-warm cycle may thus have triggered a response of the morphology and sedimentation pattern in the Elgygytgyn drainage basin.

\section{Relation between terrestrial and lacustrine records}

About the upper 2.3-2.4 $\mathrm{m}$ of the terrestrial record extracted from the permafrost corresponds in time to the upper $1 \mathrm{~m}$ of Elgygytgyn lake sediments. The upper $100 \mathrm{~cm}$ of PG1351 comprises 15000 years according to the age model given in Nowaczyk et al. (2007). Interpretations of various sediment properties in this core part reveal that the Late Pleistocene/Holocene boundary varies in resolution. Cool climate conditions contemporaneous to MIS 2 are inferred from geochemical properties, which in the Elgygytgyn basin are associated with 'cold and dry' environmental conditions (Melles et al. 2007). MIS 1 has been classified as 'warm' according to this study. Studies of diatom associations in the lake deposits support this environmental interpretation (Cherapanova et al. 2007). Magnetic susceptibility, along with changes in clay mineral abundance, exhibits a distinctive shift to warmer then back to cooler conditions following the LGM (Asikainen et al. 2007). The warmer conditions fall within the Bøling/ Aller $\varnothing$, whereas the cooler conditions match the YD well when compared with the GISP2 record. The later, 'warm-stage' Holocene period is associated with the deposition of massive muds with high magnetic susceptibilities. Sedimentation rates clearly differ between 'cold' and 'warm' stage sediments. For example, during the LGM ('cold' stage), the sedimentation rate was $4.8 \mathrm{~cm} / 1000$ years, whereas during the Holocene ('warm' stage) the sedimentation rate increased to $7.6 \mathrm{~cm} / 1000$ years (Asikainen et al. 2007). 
Fig. 6. Resulting late

Quaternary palaeoenvironmental geomorphological model for the nearshore area including the estimated lake level changes at Elgygytgyn crater lake. The box represents the location of the studied sediment core.

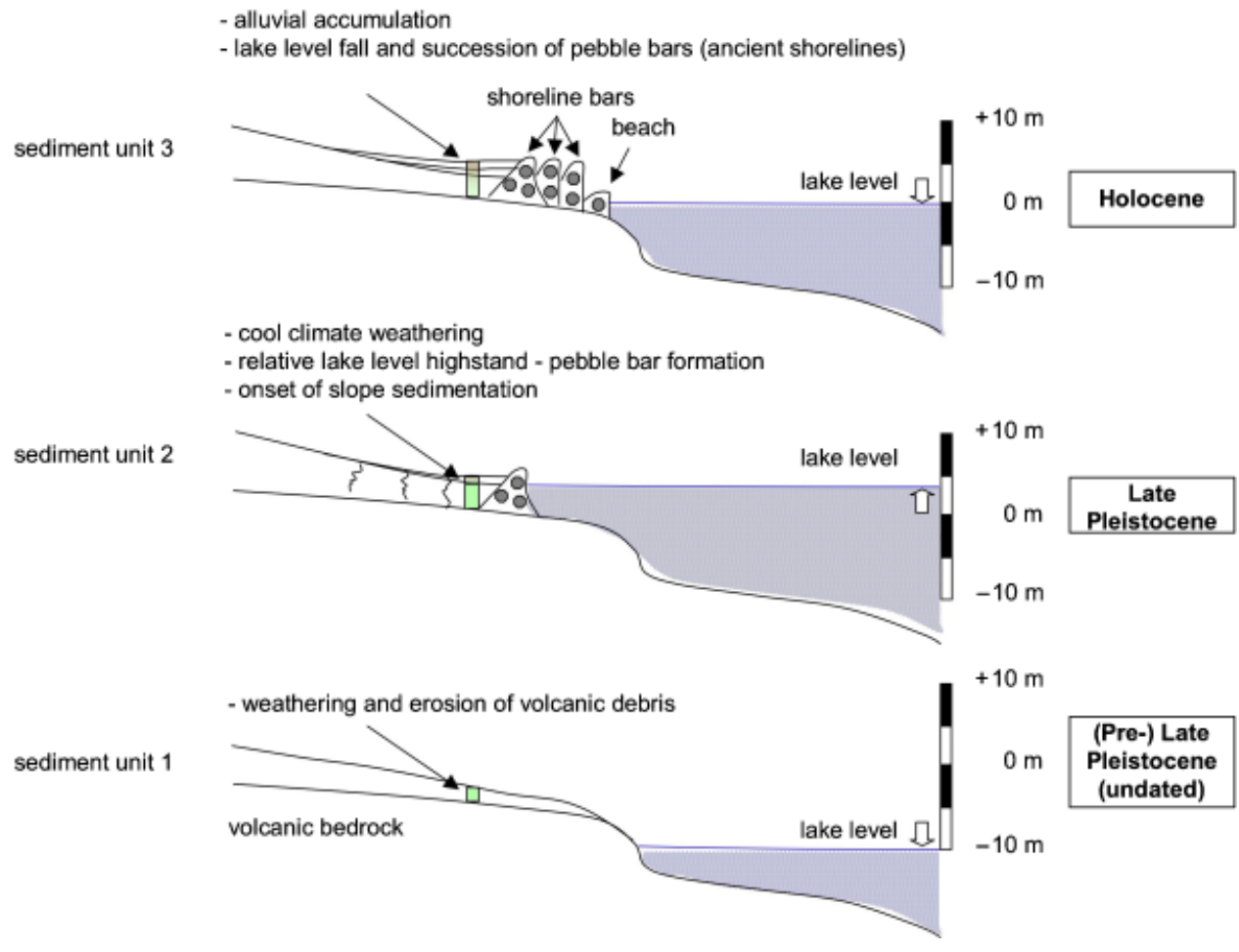

Following Minyuk et al. (2007), the modern climate is cold and during glacial stages is estimated to have been much colder. Remarkably, the inorganic chemistry record suggests a more intense chemical alteration of catchment rocks during cool climate modes such as the MIS 2 period than that ascribed to warm periods such as the MIS 1. This may correspond to conditions in sediment unit 2, where the ground ice contains higher hydrochemical concentrations, indicating enhanced chemical weathering of grains.

A palaeoclimatic reconstruction based on the pollen record in Elgygytgyn crater lake shows a climate that was cooler than the present climate between 11700 and $10900{ }^{14} \mathrm{C}$ yr BP, with herb-dominated tundra and herb shrub tundra (Lozkhin et al. 2007). This cooling period was also identified with samples from the Bering land bridge (Ager 2003). Rapid warming is indicated between 10700 and $8600{ }^{14} \mathrm{C}$ yr BP, however, when the summers were perhaps $2-4^{\circ} \mathrm{C}$ warmer than current summers (Lozkhin et al. 2007). Based on pollen and fossil insect studies, this warming is also confirmed for the Chukchi Sea area (Elias et al. 1992), a part of the former Bering land bridge. It was exposed before postglacial sea level rise flooded the area during the Early Holocene (Bauch et al. 2001). At Elgygytgyn Crater, the postglacial thermal maximum is associated with the establishment of forest tundra or perhaps gallery forests in the river valleys, before a mixed vegetation of herb-dominated and low to mid-sized shrub tundra established the modern regional vegetation (Lozkhin et al. 2007).
Studies of the catchment geomorphology (geomorphic, lithologic and stratigraphic) demonstrate that prominent terraces can be found at 35-40 $\mathrm{m}$ and 9-11 $\mathrm{m}$ above Elgygytgyn's modern lake level (Glushkova \& Smirnov 2007). A 3-5 m terrace was found in the southern crater margin (Schwamborn et al. 2006; Glushkova \& Smirnov 2007). Based on field evidence and supported by pollen data, these terraces suggest that the basin had relatively high lake levels during the Middle Pleistocene (35-40 m terrace) and the Late Pleistocene (Sartan epoch: 24-12.5 kyr) (9-11 m terrace). Together with the $4 \mathrm{~m}$ shoreline marked by the outer pebble bar, and observed in this study, the terraces reflect an overall tendency for lake level fall. A Holocene lake level fall of $5 \mathrm{~m}$ has been inferred from the $3 \mathrm{~m}$ terrace studied in the southern crater margin (Glushkova \& Smirnov 2007).

For the last $300 \mathrm{kyr}$ the lake sediment column provides a record of 24 turbidites, 19 of which are attributed to 'warm' stage sediments (Juschus et al. 2004, 2006). This includes, for example, a turbidite found at $15-19 \mathrm{~cm}$ depth (Lz 1024) and another at $23-28 \mathrm{~cm}$ (PG1351), which have been dated at $5930 \pm 40{ }^{14} \mathrm{C}$ yr BP. It has been proposed that climate changes at Elgygytgyn crater lake during the last glacial-interglacial cycle led to significant changes in sediment composition. Climate warming should thus have caused higher primary production and increased the supply of organic matter. This also implies open water conditions during summer seasons. Lake level fall and turbidites as two contemporaneous processes suggest a 
geomorphological relationship, and the general lake level fall is understood to support the release of turbidity currents. Weathering and sediment release by periglacial processes in the increasingly exposed crater valley and subsequent littoral transport may have caused sediment overloading and subaqueous slope instabilities in the lake margins.

Elgygytgyn Crater lies in a mountainous region where seismic activity could cause sediment sliding, as observed in Alpine lakes (Beck et al. 2001). At present, the region shows little seismic activity at negligible magnitudes (Parfenov \& Kuzmin 2001). However, this aspect cannot be excluded when interpreting records that reach as far back as $300 \mathrm{kyr} \mathrm{BP}$, a period not covered by the available permafrost core. The Late Pleistocene to Holocene nearshore geomorphology and sedimentation behind the shoreline bars are summarized in Fig. 6.

\section{Conclusions}

A permafrost core extracted just above the upper shoreline bar on the northern shoreline of Elgygytgyn crater lake provides insight into the late Quaternary palaeoenvironment and palaeoclimatic changes in the region. Primarily, the core shows that lake level fell. The following conclusions can be drawn:

- The minimum age of an ancient shoreline $4 \mathrm{~m}$ higher than the present lake level is $13000 \mathrm{cal}$. yr BP. This predates the onset of subaerial deposition of terrestrial deposits on the back side of the shoreline bar.

- The oxygen isotope composition of the ground ice reflects the Holocene warming following Younger Dryas cool-climate conditions.

- The warming trend interpreted from the periglacial record matches the corresponding climate interpretation derived from other records (lake and terrestrial sediments).

- A general trend of lake level fall and the transport and accumulation of periglacial sediments in the shallow parts of the lake triggered sediment mass flows into the deep lake basin of Elgygytgyn Crater.

- Climatically induced increased slope mobility and sedimentation in the catchment at the MIS 2-MIS 1 boundary can serve as a pattern that aids lake sediment archive interpretation. The catchment response should be borne in mind when studying other glacial/interglacial environmental transitions in the lake sediment archive that do not have counterparts in the periglacial record.

Acknowledgements. - We thank the Elgygytgyn scientific party for their help during the field campaign. Thanks also to Ute Bastian, Antje Eulenburg and Rita Fröhlking, who helped at various stages of sample processing. Olaf Juschus assisted with one figure. The work was sup- ported through a grant from the German Ministry for Education and Research (BMBF) within the programme 'Sedimentation im Elgygytgyn-See (NE-Sibirien) seit dem Pliozän (FKZ: 03G0586)'. The comments of J. I. Svendsen and an anonymous reviewer markedly improved the quality of the article. Paul Overduin helped with the English.

\section{References}

Ager, T. A. 2003: Late Quaternary vegetation and climate history of the central Bering land bridge from St. Michael Island, western Alaska. Quaternary Research 60, 19-32.

Asikainen, C. A., Francus, P. \& Brigham-Grette, J. 2007: Sediment fabric, clay mineralogy, and grain-size as indicators of climate change since $65 \mathrm{ka}$ from Elgygytgyn crater lake, Northeastern Siberia. Journal of Paleolimnology 37, 105-122.

Bauch, H. A., Mueller-Lupp, T., Taldenkova, E., Spielhagen, R. F., Kassens, H., Grootes, P. M., Thiede, J., Heinemeier, J. \& Petryashov, V. V. 2001: Chronology of the Holocene transgression at the North Siberian margin. Global and Planetary Change 31, 125-139.

Beck, C., van Rensbergen, P., de Batist, M., Berthier, F., Lallier, S. \& Manalt, F. 2001: The Late Quaternary sedimentary infill of Lake Annecy (northwestern Alps): An overview from two seismic-reflection surveys. Journal of Paleolimnology 25, 149-161.

Belyi, V. F. 1998: Impactogenesis and volcanism of the Elgygytgyn depression. Petrology 6, 86-99.

Brigham-Grette, J., Melles, M. \& Juschus, O. 2005: Terrace $10 \mathrm{~m}$ below lake level (chapter 5.3.2). In Melles, M., Minyuk, P., Brigham-Grette, J. \& Juschus, O. (eds.): The Expedition Elgygytgyn Lake 2003 (Siberian Arctic). Reports on Polar and Marine Research 509, 108-110.

Burn, C. R., Michel, F. A. \& Smith, M. W. 1986: Stratigraphic, isotopic and mineralogical evidence for an early Holocene thaw unconformity at Mayo, Yukon Territory. Canadian Journal of Earth Sciences 23, 794-803.

Cherapanova, M. V., Snyder, J. A. \& Brigham-Grette, J. 2007: Diatom stratigraphy of the last $250 \mathrm{ka}$ at Lake El'gygytgyn, northeast Siberia. Journal of Paleolimnology 37, 155-162.

Ehrmann, W., Melles, M., Kuhn, G. \& Grobe, H. 1992: Significance of clay mineral assemblages in the Antarctic Ocean. Marine Geology 107, 249-273.

Elias, S. A., Short, S. K. \& Phillips, R. L. 1992: Paleoecology of lateglacial peats from the Bering land bridge, Chukchi Sea shelf region, northwestern Alaska. Quaternary Research 38, 371-378.

Gebhardt, C., Niessen, F. \& Kopsch, C. 2006: Central ring structure identified in one of the world's best-preserved impact craters. Geology 34, 145-148.

Glushkova, O. Y. 2001: Geomorphological correlation of Late Pleistocene glacial complexes of Western and Eastern Beringia. Quaternary Science Reviews 20, 405-417.

Glushkova, O. Y., Lozhkin, A. V., Minyuk, P. S., Stetsenko, T. V., Belaya, B. V., Cherepanova, M. V., Brigham-Grette, J., Layer, P., Stone, D., Nolan, M., Anderson, P., Forman, S., Melles, M., Overduin, P., Zielke, A. \& Nowaczyk, N. 1999: Palaeoclimate data of Elgygytgyn Lake. Informational report. Russian Acadamy of Science, Northeast Interdisciplinary Research Institute (NEISRI) Magadan, 118 pp. (in Russian).

Glushkova, O. Y. \& Smirnov, V. N. 2005: Coastal morphology. In Melles, M., Minyuk, P., Brigham-Grette, J. \& Juschus, O. (eds.): The Expedition Elgygytgyn Lake 2003 (Siberian Arctic). Reports on Polar and Marine Research 509, 104-108.

Glushkova, O. Y. \& Smirnov, V. N. 2007: Pliocene to Holocene geomorphic evolution and paleogeography of the Elgygytgyn Lake region, NE Russia. Journal of Paleolimnology 37, 37-47.

Gravis, G. F. 1969: Fossil slope deposits in the northern Arctic asymmetrical valleys. Biuletyn Peryglacjalny 20, 239-257.

Hasholt, B. \& Hagedorn, B. 2000: Hydrology and geochemistry of river-borne material in a high arctic drainage system, Zackenberg, Northeast Greenland. Arctic, Antarctic, and Alpine Research 32, 84-94.

Juschus, O., Melles, M., Brigham-Grette, J., Dehnert, A., Gebhardt, C., Niessen, F., Minyuk, P. S. \& Wennrich, V. 2004: The significance of Late Quaternary mass movement events for the 
paleoenvironmental interpretation of sediment records from Lake El'gygytgyn, NE Siberia. Eos Trans. AGU 85(47), Fall Meeting, 13-17 December, San Francisco, USA, Suppl., Abstracts PP21B-1387.

Juschus, O., Preusser, F., Melles, M. \& Radtke, U. 2006: Applying SAR-IRSL methodology for dating fine-grained sediments from Lake El'gygytgyn, northeastern Siberia. Quaternary Geochronology, doi: 10.1016/j.quageo.2006.05.006.

Kienel, U., Siegert, C. \& Hahne, J. 1999: Late Quaternary palaeoenvironmental reconstructions from a permafrost sequence (North Siberian Lowland, SE Taymyr Peninsula) - a multidisciplinary case study. Boreas 28, 181-193.

Kokelj, S. V. \& Lewkowicz, A. G. 1999: Salinization of permafrost terrain due to natural geomorphic disturbance, Fosheim Peninsula, Ellesmere Island. Arctic 52, 372-385.

Konishchev, V. N. \& Rogov, V. V. 1993: Investigations of cryogenic weathering in Europe and Northern Asia. Permafrost and Periglacial Processes 4, 49-64.

Kotler, E. \& Burn, C. R. 2000: Cryostratigraphy of the Klondike 'muck' deposits, west-central Yukon Territory. Canadian Journal of Earth Sciences 37, 849-861.

Kunitsky, V. V. 1989: Cryolithology in the Lena River Mouth. 162 pp. Permafrost Institute Press, Yakutsk, Russia (in Russian).

Layer, P. 2000: Argon-40/argon-39 age of the Elgygytgyn impact event, Chukotka, Russia. Meteoritics and Planetary Science 35, 591-599.

Lozkhin, A. V., Anderson, P. M., Matrosova, T. V. \& Minyuk, P. 2007: The pollen record from Elgygytgyn Lake: Implications for vegetation and climate histories of northern Chukotka since the late middle Pleistocene. Journal of Paleolimnology 37, 135-153.

Melles, M., Brigham-Grette, J., Glushkova, O., Minyuk, P., Nowaczyk, N. R. \& Hubberten, H.-W. 2007: Sedimentary geochemistry of a pilot core from Elgygytgyn Lake - a sensitive record of climate variability in the East Siberian Arctic during the past three climate cycles. Journal of Paleolimnology 37, 89-104.

Melles, M., Minyuk, P., Brigham-Grette, J. \& Juschus, O. (eds.) 2005: The Expedition Elgygytgyn Lake 2003 (Siberian Arctic). Reports on Polar and Marine Research 509, 139 pp.

Meyer, H., Schönicke, L., Wand, U., Hubberten, H.-W. \& Friedrichsen, H. 2000: Isotope studies of hydrogen and oxygen in ground ice: Experiences with the equilibration technique. Isotopes in Environmental and Health Studies 36, 133-149.

Minyuk, P., Brigham-Grette, J., Melles, M., Borkhodoev, V. Ya. \& Glushkova, O. Yu. 2007: Inorganic geochemistry of Elgygytgyn Lake sediment (northeastern Russia) as an indicator of paleoclimatic change for the last $250 \mathrm{kyr}$. Journal of Paleolimnology 37, $123-133$.

Murton, J. B. \& French, H. 1994: Cryostructures in permafrost, Tuktoyaktuk coastland, western Arctic, Canada. Canadian Journal of Earth Sciences 31, 737-747.

Niessen, F., Gebhardt, C., Kopsch, C. \& Wagner, B. 2007: Seismic investigation of the Elgygytgyn impact crater lake (Central Chukotka, NE Siberia): Preliminary results. Journal of Paleolimnology $37,49-63$.

Nolan, M. \& Brigham-Grette, J. 2007: Basic hydrology, limnology, and meteorology of modern Elgygytgyn Lake, Siberia. Journal of Paleolimnology 37, 17-35.
Nowaczyk, N., Melles, M. \& Minyuk, P. 2007: A revised age model for core PG1351 from Lake El'gygytgyn, Chukotka, based on magnetic susceptibility variations tuned to northern hemisphere insolation variations. Journal of Paleolimnology 37, 65-76.

Nowaczyk, N. R., Minyuk, P., Melles, M., Brigham-Grette, J., Glushkova, O., Nolan, M., Lozkhin, A. V., Stetsenko, T. V., Anderson, P. M. \& Forman, S. L. 2002: Magnetostratigraphic results from impact Crater Elgygytgyn Lake, northeastern Siberia: A $300 \mathrm{kyr}$ long high-resolution terrestrial paleoclimatic record from the Arctic. Geophysical Journal International 150, 109-126.

Parfenov, L. M. \& Kuzmin, M. I. (eds.) 2001: Tectonics, geodynamics, and metallogeny of the Sakha Republic (Yakutia). MAIK 'Nauka/Interperiodica', Moscow, 34 pp.

Petschick, R., Kuhn, G. \& Gingele, F. X. 1996: Clay mineral distribution in surface sediments of the South Atlantic: Sources, transport, and relation to oceanography. Marine Geology 130, 203-229.

Reimer, P. J., Baillie, M. G. L., Bard, E., Bayliss, A., Beck, J. W., Bertrand, C. J. H., Blackwell, P. G., Buck, E. E., Burr, G. S., Cutler, K. B., Damon, P. E., Edwards, R. L., Fairbanks, R. G., Friedrich, M., Guilderson, T. P., Hogg, A. G., Hughen, K. A., Kromer, B., McCormac, G., Manning, S., Ramsey, C. B., Reimer, R. W., Remmele, S., Southon, J. R., Stuiver, M., Talamo, S., Taylor, F. W., van der Plicht, J. \& Weyhenmeyer, C. E. 2004: IntCal04 - Terrestrial radiocarbon age calibration, $0-26$ cal kyr BP. Radiocarbon 46, 1029-1058.

Schirrmeister, L., Siegert, C., Kuznetsova, T., Kuzmina, S., Andreev, A., Kienast, F., Meyer, H. \& Bobrov, A. 2002: Paleoenvironmental and paleoclimatic records from permafrost deposits in the Arctic region of Northern Siberia. Quaternary International 89, 97-118.

Schwamborn, G., Dix, J. K., Bull, J. M. \& Rachold, V. 2002: Highresolution seismic and ground penetrating radar - geophysical profiling of a thermokarst lake in the Western Lena Delta, Northern Siberia. Permafrost and Periglacial Processes 13, 259-269.

Schwamborn, G., Fedorov, G. \& Kupolov, A. 2005: Solifluction (chapter 4.5.4). In Melles, M., Minyuk, P., Brigham-Grette, J. \& Juschus, O. (eds.): The Expedition Elgygytgyn Lake 2003 (Siberian Arctic). Reports on Polar and Marine Research 509, 54-56.

Schwamborn, G., Meyer, H., Fedorov, G., Schirrmeister, L. \& Hubberten, H.-W. 2006: Ground ice and slope sediments archiving Late Quaternary paleoenvironment and paleoclimate signals at the margins of Elgygytgyn Impact Crater, NE Siberia. Quaternary Research 66, 259-272.

Sugimoto, A., Naito, D., Yanagisawa, N., Ichiyanagi, K., Kurita, N., Kubota, J., Kotake, T., Ohata, T., Maximov, T. C. \& Fedorov, A. N. 2003: Characteristics of soil moisture in permafrost observed in East Siberian taiga with stable isotopes of water. Hydrological Processes 17, 1073-1092.

Tomirdiaro, S. V. 1996: Palaeogeography of Beringia and Arctida. In West, F. H. (ed.): American Beginnings, 58-69, University of Chicago Press, Chicago.

Vandenberghe, J. 1995: Timescales, climate and river development. Quaternary Science Reviews 14, 631-638.

Vasil'chuk, Y. K. \& Vasil'chuk, A. C. 1998: Oxygen-isotope and ${ }^{14} \mathrm{C}$ data associated with Late Pleistocene syngenetic ice-wedges in mountains of Magadan region, Siberia. Permafrost and Periglacial Processes 9, 177-183. 